DOI 10.37882/2223-2982.2021.03-2.17

\title{
РОЛЬ КОММУНИКАТИВНОЙ КОМПЕТЕНЦИИ В ПОДГОТОВКЕ СТУДЕНТОВ ЛИНГВИСТОВ
}

\section{THE ROLE OF COMMUNICATIVE COMPETENCE IN THE TRAINING OF LINGUIST STUDENTS}

\section{O. Ishaeva}

Summary: The purpose of the presented work is to study the role of communicative competence in the preparation of students as a linguist. The analysis of the base of communicative competencies, which are a distinctive feature of the training of students of the linguistic direction, is carried out. The opinion of various scientific figures in this field is considered. Variations of the expansion and implementation of communications and competencies in this field are proposed for training linguist students. Research methods: analytical method, survey method, induction.

Keywords: communicative competence, students, linguists, linguistics, communications.

\author{
Ииаева Ольга Викторовна \\ старший преподаватель, Российский университет \\ транспорта (РУТ МИИТ) \\ ishaevao@gmail.com
}

Аннотация: Цель представленной работы - исследование роли коммуникативной компетенции в подготовке студентов-лингвистов. Проведен анализ базы коммуникативных компетенций, которые являются отличительной чертой подготовки студентов лингвистического направления. Рассмотрено мнение различных научных деятелей в данной области. Предложены вариации расширения и реализации коммуникаций и компетенций в данной области с целью подготовки студентов-лингвистов. Методы исследования: аналитический метод, обзорный метод, индукция.

Ключевые слова: коммуникативная компетенция, студенты, лингвисты, языкознание, коммуникации.
$\mathrm{B}$ эпоху глобализации, изменений в сфере трудоустройства, повышенного уровня конкурентоспособных работников необходимо делать акцент на развитии качественной системы образования, которая сможет подготовить специалистов, готовых противостоять вышеперечисленным трудностям и найти путь к успеху. Для того, чтоб обучить настоящих специалистов, важно понимать все тонкости качеств, которыми должны владеть выпускники тех или иных специальностей. Особой чертой в сфере современных вызовов является знание иностранных языков, без которых шансы построить карьеру стремятся к нулю [1]. Поэтому в этой статье речь пойдет о специалистах по языкознанию - лингвистах, а именно о роле коммуникативной компетенции в подготовке студентов-лингвистов.

Для детального анализа заданной темы необходимо ознакомиться с термином «коммуникативные компетенции», который может вызывать некорректные ассоциации. Коммуникативные компетенции - навыки, которые помогают определить нужные модели речевого поведения в разных ситуациях; у студентов-лингвистов эти навыки развиваются в четырёх направлениях: говорении, письме, слушании и чтении. Очень точно роль коммуникативных компетенций в общении определил американский лингвист Делл Хаймс: «...когда следует говорить, и когда - молчать, о чем следует говорить, с кем, когда, где, в какой форме» [2].

При углубленном анализе роли коммуникативной компетенции в подготовке студентов-лингвистов можно начать с краткого интересного факта, который докажет важность этой тематики. В начальном процессе обучения студентов-лингвистов само лишь слово «компетенция» имело уже лингвистическую смысловую нагрузку, так как адресовалось к области лингвистической подготовки. И только после этого стал популярным термин «коммуникативные компетенции» как возможность грамотно использовать модели речевого поведения за счёт знания иностранных языков и речевых норм.

Более того, роль коммуникативных компетенций в образовании лингвистов хорошо раскрывается с помощью изучения требований к хорошему специалистулингвисту [3].

Во-первых, специалист должен иметь базу билингвальной коммуникативной компетенции, включающую в себя дискурсивные, социолингвистические, социокультурные, лингвистические знания, подтвержденные высокими показателями в общеевропейской шкале требований к речевой деятельности: письму, чтению, аудированию, говорению.

Во-вторых, кроме досконального владения иностранным языком, специалист обязан знать структуру этого языка, разбираться в грамматической, лексической, стилистической системе языка; иметь представление о социологических/ культурологических данных о влиянии на формирование языка по сравнению с русским языком [4]. 
Делая краткий вывод о вышеперечисленных требованиях к специалисту-лингвисту, можно понять, что при игнорировании необходимости развития коммуникативных качеств лингвист может остаться без работы изза отсутствия первоочередных конкурентоспособных профессиональных качеств.

Для того, чтоб не прожить на своём примере негативное будущее с трудоустройством, нужно глубоко изучить базу коммуникативных компетенций, а именно:

- общий лингвистический компонент

- социолингвистический компонент

- лингвострановедческий компонент

- экстралингвистический компонент

- психолингвистический компонент

- лингводидактический компонент.

Для формирования языковой культуры будущего специалиста необходимо рассмотреть более подробно каждый из вышеперечисленных компонентов.

Общий лингвистический компонент дает азы изучения норм иностранного языка: его морфологические, лексические, синтаксические, фонетические, звуковые нормы. Это тот аспект изучения, без которого невозможно стать специалистом в этой отрасли.

Второй компонент - социолингвистический - помогает проводить параллель между языком и культурой, обществом, ведь нельзя не согласиться с тем, что язык является признаком объединения народа, показывая национальную культуру, ценности и качества нации.

Лингвострановедческий компонент направлен на изучение углубленных знаний в географический, политический, экономический, исторический отрасли той или иной страны для более детального, а не поверхностного понимания оборотов и норм иностранного языка.

Экстралингвистический компонент необходим для ориентации студентов-лингвистов в ситуативных контекстах языка, таких как терминология, присуща банковскому, финансовому, историческому диалекту.

Психолингвистический необходим для ориентации в психологических законах языковой практики, в том числе и для умения декодировать полученную информацию в процессе слушания, или же наоборот умения кодировать информацию в процессе говорения.

И последний, а именно лингводидактический компонент, должен обеспечить исследования процесса формирования коммуникативной компетенции иностранного языка.

Рассматривая вышеперечисленные аспекты подготовки студентов-лингвистов, можно прийти к выводу, что качественное обучение базируется именно на коммуникативных компетенциях. Поэтому, если забрать хотя бы одну из них, теряется полноценность получен- ных в стенах университета знаний.

Кроме уже упомянутых признаков важности коммуникативных компетенций для студентов-лингвистов, роль этих компетенций можно осознать и при анализе актуальных проблем в сфере коммуникации современных студентов.

Поскольку в современной мире большинство студентов, в том числе и студентов гуманитарных наук использует компьютерные технологии, Интернет и социальные сети для коммуникации, то развивается межличностная отчужденность, для которой характерно появление однобокой коммуникативной компетентности из-за отсутствия критического осмысления информации и умения четко формулировать свои мысли, так как благодаря использованию средств связи студент с легкостью может найти ответы на задачи, тесты и так далее. Кроме того, из-за развития цифровых технологий в обществе студенты уделяют меньше внимания коллективному и межличностному общению, из-за чего эта способность начинает деформироваться и становиться проблематической не только в профессиональной, но и в повседневной жизни [5].

Более того, развитие цифровых технологий и отсутствие межличностной коммуникации грозит не только отдельно взятым людям, но и всему обществу. Потому как в современных условиях между людьми цифровая коммуникация выходит на первый и главенствующий план, происходит трансформация процесса общения.

Как говорил немецкий философ и социолог Юрген Хабермас: «...коммуникация - это основополагающий компонент социального прогресса». Поэтому аспект объединения и структурирования общества зависит, в первую очередь, от коммуникативной взаимосвязи его членов. А поскольку коммуникативные навыки связаны не только с развитием связей между людьми, но и с процессом мыследеятельности, то из-за ухудшения коммуникативных компетенций общество ожидает интеллектуальный регресс.

Процесс отчуждения из-за ухудшения коммуникации будет наблюдаться не только в обществе, но и в проблемах отдельного индивида. Если опыт социального единства будет падать в силу недостаточной коммуникации, то индивид не будет видеть себя в качестве элемента органической целостности и будет воспринимать внешний социум как враждебную стихию, что может вылиться в появление трагического одиночества и отчуждения.

На первый взгляд, вышесказанное может показаться слишком преувеличенным. Но главное - то, что старт этим проблемам в социуме заложен уже давно. Подтверждением этого могут являться опросы, проведенные среди студентов гуманитарных, в том числе и лингвистических наук, которые считают, что уровень их коммуникативных компетенций ниже среднего, по- 
скольку они почти не владеют информацией об истории, культуре, геополитике народов, говорящих на других языках.

Поэтому из озвученного можно сделать вывод, что коммуникативные компетенции важны в образовании сегодня, как никогда. А поскольку студенты-лингвисты стоят в первых рядах тех, кто несет ответственность за развития таких компетенций, то их обучение в университетах должно базироваться на задаче «научиться жить вместе», которая была сформулирована в результате международного исследования ЮНЕСКО как один из главных и необходимых четырех «столпов образования» в двадцать первом веке.

Для того, чтоб воплотить в реальность задачу «научиться жить вместе», необходимо рассмотреть несколько пунктов, которые помогут студентам улучшить качество владения коммуникативными компетенциями.

Во-первых, для преодоления проблемы низкого владения коммуникативными компетенциями, нужно внедрять системное исследование процесса облучения в университете с позиции своевременного и компетентностного модульного оценивания знаний, которое поможет педагогам смоделировать нужную схему преподавания и расставить акценты на конкретные приемы, техники, методы изучения иностранного языка.

Во-вторых, необходимо увеличивать количество материалов, которые раскроют нужные лингвистические компоненты (культуролингвистический, социолингвистический, социокультурный и так далее). Студенты должны обучаться всем четырём типам речевой деятельности: письму, чтению, аудированию, говорению.

B-третьих, для лучшего понимания моделей и норм иностранного языка нужно применить 4 этапа по улучшению коммуникативных компетенций: узнавание (наблюдение и изучение культуры носителей другого языка, этап «наклеивания ярлыков» на чужую культуру); принятие/ отторжение (формирование нейтрального отношения к культуре другого народа, общего взгля- да на мир); интеграция/ этноцентризм (формирование возможностей эмпатии, становление вторичной языковой личности); трансцендентность (формирование уважения к иным культурам и ценностям). Необходимость такой схемы в том, чтоб изучать языковую и культурную базу других народов постепенно, вырабатывая разные подходы.

Коммуникативные компетенции представляют собой очень важный процесс обучения в системе лингвистических направлений, потому как абсолютно точно можно свидетельствовать о необходимости выстраивания системы коммуникативных компетенций с целью демонстрации качественного уровня организации образовательной деятельности. Данный фактор можно доказать тем доводом, что коммуникации в лингвистической структуре являются одним из важнейших факторов обеспечения стратегии взаимодействия между единицами общества.

Соответственно, нельзя игнорировать тот факт, что роль коммуникативной компетенции в данной сфере абсолютно точно невозможно преувеличить, потому как именно представленная компетенция выступает в роли главенствующего звена выстраивания качественной системы образовательного процесса.

Подводя итоги этой статьи, можно сделать вывод, что изучение коммуникативных компетенций в процессе обучения студентов-лингвистов необходимо по ряду причин: базовые навыки в своей профессиональной сфере, формирование востребованных требований к хорошему специалисту-лингвисту, развитие фактора социального единства, повышение качеств в межличностной коммуникации, повышение уровня знаний о культуре, истории, экономики, общей жизнедеятельности других стран и народов. Более того, для применения роли важности коммуникативных компетенций в жизни, нужно выполнить ряд изменений в процессе обучения студентов: сделать акцент на задаче «научиться жить вместе», проводить своевременное оценивания знаний студентов, подавать разнообразите материалов, преподносить знания в четырехэтапной схеме обучения.

ЛИТЕРАТУРА

1. Колмогорова А.В., Чистова Е.В., Мартынюк К.В. «Ризоморфный клубок»: когниция vs коммуникация: монография / отв. ред. А.В. Колмогорова. Красноярск: СФУ, 2017. 252 c.

2. Базылев В.Н., Красильникова В.Г. Дидактика перевода. Хрестоматия и учебные задания: учеб. пособие. Изд-е 5-е, стер. М.: Флинта, 2017. 128 с.

3. Гуреева А.А. Переводчик XXI века - агент дискурса: коллективная монография / науч. ред. В.А. Митягина, А.А. Гуреева. Изд-е 2-е, стер. М.: Флинта, 2017. 278 c.

4. Дубкова 0.В., Колышкина С.С. Теория и практика перевода иностранных текстов: восточные языки: учебное пособие. Новосибирск: Изд-во НГтУ, 2017. $175 \mathrm{c}$.

5. Илюшкина М.Ю. Теория перевода: основные понятия и проблемы: учебное пособие. Изд-е 3-е, стер. М.: Флинта, 2017. 84 с.

(с) Ишаева Ольга Викторовна (ishaevao@gmail.com). 